\title{
Obstacle Factors on Evidence System of Urine Test Result on Drugs Cases in National Narcotics Board of North Sumatera Province, Indonesia
}

\author{
Rizkan Zulyadi \\ Universitas Medan Area, Medan, Indonesia \\ rizkan@staff.uma.ac.id
}

\section{Abstract}

This study aims to discuss what factors inhibit the system of proving the results of urine test narcotics cases in the National Narcotics Agency of North Sumatra Province. the system of proving urine test results in narcotics cases in the National Narcotics Agency of North Sumatra Province that the opinion of Dr. Romi as a medical team at BNN said the function of the urine test is to determine whether or not someone has used narcotics because in the urine it will be known whether there is a narcotic content or not that can only be known for 1-7 days after use and urine tests are carried out with aids in the form of stick test. Provide counseling about Narcotics and the presence of BNN in North Sumatra Province in educational institutions. Provide counseling about Narcotics and the presence of BNN in each region in the Province of North Sumatra as a research location. Establish cooperation with parties both public and private to provide counseling in each institution.
Keywords

proof of urine test

results; narcotics cases;

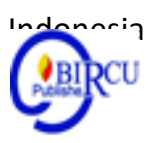

\section{Introduction}

Narcotics are substances that are familiar. "Narcotics is one of the drugs needed in the world of medicine, as well as in the field of research for educational purposes, scientific development and its application." 1 With the intention of medicinal treatment, its availability needs to be guaranteed but what is happening at the moment is the abuse of narcotics is a big problem because can also cause prolonged dependence if used not in accordance with the dose and close supervision. Narcotics abuse also results in physical, mental, social, security and public order disorders.

Narcotics (Narcotics and illegal drugs) or drugs (Narcotics, Psychotropics, and other addictive substances) are a type of substance whose use in Indonesia is regulated in the Drug Act contained in State Gazette No. 278 of 1972 and supplemented and perfected with State Gazette No. 419 of 1949. The term narcotics used here is not "narcotics" in pharmacology, but it is synonymous with "drug" which is a type of substance which when used will bring certain effects and effects on the body of the user that is affecting consciousness, and impulses that can affect towards human attitudes and behavior. These effects can be in the form of tranquility, stimulants (not sex stimulation), and cause hallucinations. Narcotics substances found by humans are intended for the field of medicine. Therefore in the provisions of the law regarding narcotics its use is regulated legally under the supervision and responsibility of doctors and pharmacists. The use of narcotics at a dose regulated by a doctor for medicinal purposes does not have harmful side effects for the body of the person concerned. 
In data released by the North Sumatra Regional Police, narcotics crime cases were recorded as many as 5,926 cases in 2018. This number has increased compared to the previous year of 5,897 cases. North Sumatra Police Chief Inspector General Agus Andrianto, who presented notes during 2018, considers this figure to be still high. Although it has been confirmed to all members work hard to continue to reduce the crime rate of illicit goods.

Various efforts to tackle narcotics abuse, both preventive and reperceive. One way to prove someone is using narcotics or not is to use a urine test, besides that there are many other ways to prove someone is using narcotics or not by performing blood tests, hair tests, dioxyribonucleic acid (DNA) tests, and / or section tests other bodies in a way carried out in accordance with the development of science and technology. This provision is regulated in Article 75 letter 1 of Law Number 35 Year 2009 concerning Narcotics which states: "In the course of conducting an investigation, BNN investigators are authorized to conduct urine tests, blood tests, hair tests, dioxyribonucleic acid (DNA) tests, and / or test other body parts. " From the explanation of Article 75 letter 1 of Law Number 35 Year 2009 that the investigator can carry out all the tests, but in reality from the various tests which are a way to prove someone uses narcotics, the investigator will only carry out one of the tests the.

\section{Review of Literature}

\subsection{Overview of Narcotics}

The word narcotics has something to do with the word naram in Greek which means to be rigid (seizure), in medical terminology the term narcose or narcosis means to be narrated especially during surgery (surgery), this meaning which is likely to be contained in the Latin term narcotics (anesthetic), which then means getting wider so it's the same as drugs in English.

In general, what is meant by narcotics is a type of substance that can cause certain effects for people who use it, namely by entering it into the body. According to Law Number 35 Year 2009, Narcotics are substances or drugs derived from plants or non-plants, both synthetic and semisynthetic, which can cause a decrease or change of consciousness, loss of taste, reduce to eliminate pain, and can cause dependence, which divided into groups as attached in this Act. The term narcotics used in this study is the same as "drug", which is a type of substance that when used will bring certain effects and effects on the user's body, namely:

a. Affects awareness;

b. Provide encouragement that can affect human behavior;

c. These effects can be:

1) Sedative;

2) Stimulant (not sex stimulation);

3) Cause hallucinations (the wearer is unable to distinguish between fantasy and reality, loss of awareness of time and place).

Narcotics that are famous in Indonesia today are derived from the word "Narcotics", which is the same meaning as the word narcosis which means to anesthetize. The nature of these substances mainly affects the brain causing changes in behavior, feelings, thoughts, perceptions, awareness, hallucinations, in addition to being used for anesthesia. The purpose of making arrangements regarding narcotics crime based on Article 4 of Law No. 35 of 2009, namely: 
a. Guarantee the availability of Narcotics for the benefit of health services and / or the development of science and technology;

b. Prevent, protect and save the Indonesian people from narcotics abuse;

c. Eradicate the illicit trafficking of narcotics and narcotics precursors; and

d.Ensure arrangements for medical and social rehabilitation efforts for Abusers and Narcotics addicts.

\subsection{General Review of Narcotics Crimes}

Narcotics abuser is a criminal offense because there is a legal regulation governing narcotics abuser, namely Law No. 35/2009 concerning Narcotics, so that someone who abuses narcotics can be subject to sanctions in accordance with applicable regulations. "Drug abuse itself is a drug user that is carried out not for medicinal purposes, but because it wants to enjoy its effects, in excess amounts that are less regular, and last long enough, causing physical, mental health and social life disorders." 14 Main Actors According the provision of criminal law for narcotic offenders basically can be divided into:

\section{a. Main offender \\ b.Participants \\ c. Helpers}

If you look at the three forms of abuse above, then the closed action is the possibility of other criminal acts such as murder, theft, extortion, fraud, etc., because when a user is in a state of withdrawal (dropping out of drugs) due to the effects of dependence from narcotics then usually people the sakaw had done various ways to be able to obtain the substances or drugs they needed so that because they did not have the money to buy the substances or illegal drugs they had committed other criminal acts as exemplified above.

In Law No. 35 of 2009 concerning Narcotics has stipulated criminal provisions against narcotics misuse, which are contained in Article 111 to Article 148. For narcotics dealers and users there are different articles in terms of regulating the type of system of formulation of types of criminal sanctions (strafsoort) and the formulation system the duration of criminal sanctions (strafmaat), which will be explained as follows: In Law No. 35 of 2009 concerning Narcotics for dealers, there are two types of strafsoort formulation systems, namely the cumulative formulation system between imprisonment and fines (Articles 111, 112, 113, 116, $117,120,122,123,124,125$ Narcotics Law) and a joint formulation system between capital punishment, life imprisonment or imprisonment and fines (Articles 114, 115, 118, 119 Narcotics Law). Then for the formulation system of the duration of criminal witnesses (strafmaat) in the Narcotics Act there are also two formulations namely fixed / indefinite sentence system or maximum system and determinate sentence system (Articles 111, 112, 113, 114, 115, 116, 117, 118, 118, 119, 120, 121, 122, 123, 124, 125 Narcotics Law).

\subsection{Evidence System}

The evidentiary system is the regulation of the types of evidence that may be used, the decomposition of the evidence, and by the ways in which the evidence is used and by how the judge must form his conviction before the court hearing. Types of Proof Systems Based on the literature, there are 4 (four) types of proof systems / theories, namely:

- A positive law-based verification system (positive wettelijke Bewijstheorie).

- A system of proof based on a judge's conviction (conviction intime).

- The proof system is based on the judge's beliefs with logical reasons (La conviction raisonee).

- The system of proof is based on the law negatively (negatief wettelijke). 
a. Proof system adopted by the Criminal Procedure Code

Of the four evidentiary systems described above, the Criminal Procedure Code adheres to a law-based proof system negatively (negatief wettelijke). This can be seen based on Article 183 of the Criminal Procedure Code which states: "A judge may not convict a person unless at least two legal pieces of evidence obtain the conviction that a criminal act actually occurred and that the defendant is guilty of committing it." By listening to the sound of Article 183, the judge's confidence in the occurrence of a criminal offense and the culprit is that the defendant is based on a minimum of two valid evidences as stated in Article 184 of the Criminal Procedure Code. Through Article 183 of the Criminal Procedure Code it is also determined that the basis of the judge's conviction is a minimum of 2 (two) valid evidences. This means that if there is only one piece of evidence it cannot be used to prove the accused's guilt. So there must be / or added other evidence.

To get a more adequate description of the evidentiary system adopted by the Criminal Procedure Code, it is clarified again as follows:

- Called wettelijk or according to the law because for proof, the law determines the type and amount of evidence that must be available, and

- Called negative because of the types and the number of evidences determined by the law that can not make the judge have to convict a person of the defendant, if the types and the number of evidence that has not been able to cause confidence in him that a crime had actually taken place and that the defendant was guilty of the crime.

Thus the minimum of two valid evidences must be fulfilled by the public prosecutor, but if indeed the judge does not have confidence in the accused's guilt then the criminal cannot be handed down. This negative proof system is a combination of a system of proof according to the law with a system of proof according to conviction or conviction in time which then gives rise to the formulation of whether a defendant is determined by the judge's conviction based on the method and legal evidence according to the law.

\section{b. Overview of Urine Tests in Narcotics Cases}

Forensics (derived from the Latin forensis meaning "from outside", and allied with the word forum which means "public place") is a field of science used to help the process of establishing justice through the process of applying science or science. Easier understanding, Forensic Science is the science of conducting examinations and collecting physical evidence found at the scene of the case and then presented in court.

In this group of forensic sciences are known among others forensic physics, forensic chemistry, forensic psychology, forensic medicine, forensic toxicology, forensic psychiatry, forensic computers, and so on. Forensic medicine can be simply defined as the application of medical science in the enforcement of justice. Broadly speaking, this science can be divided into three groups of disciplines, namely forensic pathology, clinical forensic science, and forensic laboratory science.25 Urine test which is one way to determine whether or not someone is using narcotics is included in the forensic laboratory science group . Forensic laboratory science is part of forensic medicine.

\subsection{Duties and Functions of National Narcotics Board of North Sumatera Province a. Duty}

Develop and implement national policies regarding the prevention and eradication of illicit abuse and illicit trafficking of Narcotics and Narcotics Precursors; Prevent and eradicate abuse and illicit trafficking of Narcotics and Narcotics Precursors; Coordinate with the Head of the Indonesian National Police in the prevention and eradication of illicit abuse and illicit trafficking of Narcotics and Narcotics Precursors; Improve the ability of medical 
rehabilitation institutions and social rehabilitation of Narcotics addicts, both organized by the government and the community; Empowering the public in the prevention of the abuse and illicit trafficking of Narcotics and Narcotics Precursors; Monitor, direct and improve community activities in the prevention of the abuse and illicit trafficking of Narcotics and Narcotics Precursors; Undertake bilateral and multilateral cooperation, both regional and international, to prevent and eradicate illicit trafficking of Narcotics and Narcotics Precursors; Developing Narcotics and Narcotics Precursor laboratories; Carry out administrative investigations and investigations on cases of illicit abuse and illicit trafficking of Narcotics and Narcotics Precursors. Make an annual report on the implementation of duties and authority.

\section{b. Function}

Formulation and formulation of national policies in the field of prevention and eradication of narcotics, psychotropic abuse and narcotics abuse and precursors and other addictive substances except addictive substances for tobacco and alcohol which are further abbreviated with the prevention of abuse and illicit trafficking of narcotics and narcotics precursors (P4GN); Formulation, formulation and stipulation of norms, standards, criteria and procedures to prevent the abuse and illicit trafficking of narcotics and narcotics precursors (P4GN); Compilation of BNN planning, program and budget; Preparation and formulation of preventive technical policies, community empowerment, eradication, rehabilitation, law and cooperation in the field of prevention of narcotics abuse and illicit trafficking and narcotics precursors (P4GN), Implementation of national policies and technical policies to prevent narcotics abuse and illicit trafficking and narcotics precursors (P4GN) ) in the areas of Prevention, Community Empowerment, Eradication, Rehabilitation, Law and Cooperation. Implementation of technical guidance in the field of prevention of the misuse and illicit trafficking of narcotics and narcotics precursors (P4GN) to agencies in the BNN environment; Coordination of relevant government agencies and community components in the framework of the formulation and formulation and implementation of national policies in the field of preventing the abuse and illicit trafficking of narcotics and narcotics precursors (P4GN). Implementation of guidance and administrative services within the BNN; Implementation of facilitation and coordination of the community participation container; Carry out investigations and investigate the misuse and illicit trafficking of narcotics and narcotics precursors; Implementation of the termination of organized crime networks in the field of narcotics, psychotropic substances, and precursors and other addictive substances, except addictive substances for tobacco and alcohol; Coordination of relevant government agencies and community components in the implementation of rehabilitation and reintegration into the community and follow-up care for abusers and / or addicts of narcotics and psychotropic substances and other addictive substances except addictive substances for tobacco and alcohol at the central and regional levels.

\section{Research Method}

The method of approach used in this research is normative juridical, which is a research that deductively starts an analysis of the articles in the legislation governing the above problems. Juridical legal research means research that refers to existing literature studies or to secondary data used. Secondary data is a source of research data obtained through intermediary media or indirectly in the form of books, notes, evidence that already exists, or 
archives both published and not publicly published. In other words, researchers need to collect data by visiting libraries, study centers, archive centers or reading many books related to their research.

This research is a descriptive analysis, research that seeks to describe a phenomenon, event, event that is happening now. The data analysis process is actually a work to find themes and formulate hypotheses even though there is actually no definite formula for formulating hypotheses. Existing data were analyzed with a view to describing the characteristics of the sample on the variable under study, then drawing conclusions. While the data analysis technique used is qualitative analysis, the data obtained is then compiled systematically and then analyzed qualitatively based on discipline. To analyze the research data used qualitative data analysis methods. "Qualitative data is non-numeric data that can be obtained from records, observations, interviews, or written material (laws, documents, books, etc.) in the form of verbal expressions." Processing and analysis of qualitative data emphasizes more his analysis on deductive and inductive inference processes and on the dynamics of the relationship between observed phenomena, using scientific logic.

\section{Discussion}

\subsection{Evidence System of Urine Test Result on Drugs Cases in National Narcotics Board of North Sumatera Province, Indonesia}

Researchers conducted research at the National Narcotics Agency of North Sumatra Province by conducting interviews with the authorities in providing information specifically in this study. The results of the interview with Dr. Romi at the Medan National Narcotics Agency Clinic that the purpose of a urine test is to find out in a person's body whether or not there is a narcotic substance.

Urine examination not only can provide facts about the kidneys and urinary tract, but also about physiology of various organs in the body such as: liver, bile ducts, pancreas, adrenal cortex, etc. Normal clear transparent urine, light yellow color in the urine comes from the substance bilirubin and biliverdin. Normal human urine consists of water, urea, uric acid, ammonia, creatinine, lactic acid, phosphoric acid, sulfuric acid, chloride, and salt, whereas in certain conditions can be found excessive substances such as vitamin C, drugs (Ma Rufah, 2011) 6. The process of formation of urine Kidney is a place that is used to remove metabolic waste in the form of urine. The process of formation of urine through three stages, namely through the mechanism of filtration, reabsorption and secretion. As the name implies, urinalysis or urine test is a method of examination using urine (urine) to detect any interference in the body. Normally, healthy urine is identical to light yellow. The color of the urine will change if something turns out wrong with the function of your organs.

Based on the results of interviews conducted by the author with the National Narcotics Agency of North Sumatra Province that according to the informant the results of the urine test will be used as evidence evidence and based on Article 184 paragraph (1) of the Criminal Procedure Code which explains the legal evidence is 5 that is witness testimony, expert statements, letters, instructions and statements of the defendant, so from the results of interviews with respondents the investigator at the National Narcotics Agency of North Sumatra Province who explained that the urine test results will be used as evidence evidence instructions in accordance with the provisions of Article 184 paragraph (1) of the Criminal Procedure Code. Understanding the instructions in Article 188 paragraph (1) of the Criminal Procedure Code, namely: Guidelines are actions, events or circumstances that are due to the agreement, both between one another, and with the criminal act itself, indicating that a criminal act has occurred and who is the culprit. The results of the urine test will be made in 
the form of a letter and in accordance with the provisions of Article 188 paragraph (2) of the Criminal Procedure Code, the instructions can only be obtained from witness statements, letters, and statements of the defendant. The urine test conducted by the National Narcotics Agency of North Sumatra Province as follows:
a. Socialization
b. Training for Trainers
c. General Election
d. Position Auction
e. Technical guidance.

\subsection{Obstacle Factors on Evidence System of Urine Test Result on Drugs Cases in National Narcotics Board of North Sumatera Province}

The results of interviews with investigators of the National Narcotics Agency of North Sumatra Province that are the factors that inhibit the System of Proving the Urine Test Results of Narcotics Cases in the National Narcotics Agency of North Sumatra Province are as follows:

1) According to Investigators at the National Narcotics Agency of North Sumatra Province that in general the urine test is quite optimal in terms of determining whether or not someone is using narcotics and according to respondents basically the suspect is more pleased with the existence of this urine test because with a urine test then most likely the suspect Article 127 of Law Number 35 of 2009 concerning narcotics, which may be subject to the lowest criminal threat compared to other articles in Law Number 35 of 2009 concerning Narcotics. However, although it is already quite optimal, there are still factors that hinder the proof of narcotics crime in the Narcotics National Agency of North Sumatra Province.

2) Negligence on the part of the investigator

Based on the results of interviews conducted by the author of the informants in National Narcotics Board of North Sumatera Province that this urine test is very important to be done on suspects to determine whether or not someone has used narcotics, so this urine test must be done. If this urine test is not carried out, then the examination program file from the investigator is abundant to the Medan District Court without a letter from the urine test result, the prosecutor will return the file because it is considered incomplete, which is a problem if the file is returned because it does not attach the urine test results so the investigator will do a urine test on the suspect, but the urine of the suspect can no longer determine whether or not the suspect is using narcotics because the urine test itself has a weakness that is within a certain time this urine will be neutral by itself so that the urine test results will be negative.

3) No evidence is found In actual practice the problem is if the investigator when arresting someone suspected of abusing narcotics but when the investigator makes an arrest the investigator cannot find evidence, whether in the form of narcotic evidence and / or equipment used for consume narcotics, but when a urine test is done, the urine test from the examinee is positive using narcotics and because the evidence is not found then the investigators will only arrest while looking for evidence to strengthen the investigator's reason to submit the case to the Medan District Court because according to respondents urine test is only as evidence evidence that is only complementary.

According to the National Narcotics Agency (BNN) investigator in North Sumatra Province on Wednesday 27 June 2019, that there are many factors inhibiting the proof of narcotics crime through urine test results in the legal territory of North Sumatra Province during the investigation stage, namely: 
1) Inaccurate urine test It means that it is difficult to prove that the percentage of accuracy of this urine test is lowest when compared to other tests such as hair tests or DNA tests where the percentage of hair tests or DNA tests can reach $100 \%$ so it can be concluded that the urine test hard to prove someone is right or not has used narcotics. This urine test is inaccurate so that the investigators find it difficult to prove, meaning that it is difficult to prove that it is difficult to determine whether the suspect is a dealer or user and / or dealer and user.

2) This urine test quickly disappears. The point is fast disappearing that is urine from someone who uses narcotics can be sterile or disappear by itself within 2-3 days so that when doing urine tests on someone who has used narcotics for more than 2 days it is likely that the urine of that person is negative using narcotics.

3) Absence of other test kits The purpose of the absence of other test kits to determine whether or not someone is using narcotics is that the tools to test hair and DNA tests do not yet exist in North Sumatra Province where if the investigators conduct hair tests and tests DNA to determine whether or not someone is using narcotics then hair samples and DNA testing.

4) Difficult to determine as a dealer or just store The point is that if the urine test is negative but the evidence is found then the investigator will be difficult to determine whether the suspect is a dealer or just keep it. Based on the results of interviews conducted by the author with the investigator at the North Sumatra Province BNN office, which is a factor inhibiting the proof of narcotics crime using urine test results as evidence that is a means of supporting facilities for law enforcement because it is known that this urine test has weaknesses i.e. rapid loss of narcotics in urine when using narcotics and also has lower accuracy compared to hair tests and DNA tests that have $100 \%$ accuracy but if you want to use hair tests and DNA tests to determine whether or not someone has used narcotics, in North Sumatra Province still lacks tools so this is a factor that hinders the verification of narcotics crime by using urine test results.

\section{Conclusion}

Factors inhibiting the system of proving the results of urine test narcotics cases in the National Narcotics Agency of North Sumatra Province is that urine test results can be manipulated by certain elements depending on the ethics of each party. The point is manipulated, that is, the urine test results can be tested positive for using narcotics, but changed to negative using narcotics or vice versa. Another inhibiting factor is the aspect of law enforcement officials who use the weakness of Law Number 35 Year 2009 Regarding Narcotics.

\section{References}

Ashofa, B. (2011). Metode Penelitian Hukum. Bandung: Rineka Cipta.

Broto, A. W. (2002 ). Praktek Peradilan Pidana, Proses Persidangan Perkara Pidana. Jakarta: PT. Galaksi Puspa Mega.

D, Soedjono. (2006). Kejahatan dan Penegakan Hukum di Indonesia. Jakarta: PT. Rineka Cipta.

Taufik. (2011). Tindak Pidana Narkotika. Jakarta: Ghalia Indonesia.

Hamzah, A. (2010). Perkembangan Hukum Pidana khusus. Jakarta: Rineka Cipta. 
Hatdjon, P. M. (2007). Perlindungan Hukum Bagi MAsyarakat Indonesia. Surabaya: Bina Ilmu

Joewana, L. H. (2010). Pencegahan dan Penanggulangan Penyalahgunaan Narkoba Berbasis Sekolah Jakarta: Balai Pustaka

Kunto, S. A. (2010). Metode Penelitian Sosial. Bandung: Graha Grafika

Kusumo, S. M. (2013). Mengenal Suatu Hukum Pengantar. Yogyakarta: Liberty

Makarau, T. (2005). Tindak Pidana Narkotik. Jakarta: Ghalia Indonesia. Mardani. (2008)

Penyalahgunaan Narkoba dalam Perspektif Hukum Islam dan Hukum Pidana Nasional. Jakarta: PT. Raja grafindo Persada

Moeljatno. (2008). Asas-asas hukum Pidana. Jakarta: Bina Aksara.

Raharjo, S. (2005). Ilmu Hukum. Bandung: Citra Aditya Bakti. Safaat.

J. A. (2006). Teori Hans Kelsen Tentang Hukum. Jakarta: Sekjen Dan Kepanitraan MK Ri

Syamsuddin. (2012). Operasionalisasi Penelitian hukum. Jakarta: PT. Raja Grafindo Persadda.

Tresna, R. (2000). Komentar HIR. Jakarta: Pradnya Paramita. Waluyo, B. (n.d.). Penelitian Hukum dalam Praktek . Jakarta: Sinar Grafika 